\title{
HYDROGEOCHEMICAL CONDITION OF THE PIKROLIMNI LAKE (KILKIS GREECE)
}

\author{
Dotsika E. ${ }^{1}$, Maniatis Y. ${ }^{1}$, Tzavidopoulos E. ${ }^{1}$, Poutoukis D. ${ }^{2}$ and Albanakis K. ${ }^{3}$. \\ ${ }^{1}$ Inst. of Material science, N.C.S.R. «Demokritos», Aghia Paraskevi, Attiki \\ ${ }^{2}$ General secretary Research and Technology, Mesogion 12-14, Athens \\ ${ }^{3}$ School of Geology, Aristotle University of Thessaloniki
}

\section{ABSTRACT}

In order to understand the hydrogeochemical conditions of the basin of Pikrolimni we collected water samples from the borehole in the thermal spa of Pikrolimni and samples of brine and sediments from the lake. We also sampled fresh water of the region. The depth of the borehole in the thermal spa is approximately 250 meters. This water is naturally sparkling, with a metallic aftertaste and a slight organic smell.

The samples were taken twice during the year: in summer (8/2002) and in winter (2003). The analytical scheme includes field measurements of temperature, conductivity and $\mathrm{pH}$.

Major ions $\left(\mathrm{Na}^{+}, \mathrm{K}^{+}, \mathrm{Ca}^{2+}, \mathrm{Mg}^{2+}, \mathrm{Cl}^{-}, \mathrm{Br}^{-}, \mathrm{SO}_{4}{ }^{2-}, \mathrm{CO}_{3}{ }^{2-}, \mathrm{HCO}_{3}{ }^{-}, \mathrm{NO}_{3}{ }^{-}\right), \mathrm{F}^{-}$and $\mathrm{Br}^{-}$were determined, in laboratory, according to standard analytical methods. Samples were also subjected to isotopic analysis of $\delta^{18} \mathrm{O}$ and $\delta^{2} \mathrm{H}$.

The results from the chemical analyses of the samples, show that the waters taken from the borehole, are of the type $\mathrm{Mg}-(\mathrm{Na}-\mathrm{Ca})-\mathrm{HCO}_{3}$ and the salts of the lake are of the type $\mathrm{Na}-\mathrm{Cl}-\left(\mathrm{CO}_{3}\right.$ $\mathrm{SO}_{4}$ ).

The salts of the lake result from mixing and condensation of the waters which are accumulated in the basin of the lake, and come not only from sources that feed the lake, e.g. waters from borehole, but also from rain water. The waters of these sources are mainly of meteoritic origin and circulate deeply, mixing probably with salt water of deeper and probably of warmer horizons. The latter comes in agreement with the hydrothermal field, which exists in the area. From hydrochemical data, the brines of summer clearly correspond to waters, which have been submitted under high degree of evaporation: they are residual mother solutions before the step of the precipitation of halite.

During winter, dilution of brines and dissolution of depositing minerals by fresh water are observed. On the other hand, evaporating conditions are created in the lake during summer.

\section{INTRODUCTION}

Located in the north part of Greece, Pikrolimni is one of the Greek lakes where, during summer, the evaporation of the body of its water, produces lacustre evaporate. A study undertaken in 2002 investigated the origin of these waters and the conditions, which are responsible for the formation of salt (Ignatiadou et al., 2003) using environmental tracers.

\section{SAMPLING AND ANALYSIS}

Samples were taken from the borehole in the thermal spa of Pikrolimni and samples of brine and sediment from the lake itself. We also sampled fresh water of the region. The depth of the borehole in the thermal spa is approximately 250 meters. This water is naturally sparkling, with a metallic aftertaste and a slight organic smell.

The samples were taken twice during the year: in summer and in winter (2003). The analytical scheme includes field measurements of temperature, conductivity and $\mathrm{pH}$. 
Major ions $\left(\mathrm{Na}^{+}, \mathrm{K}^{+}, \mathrm{Ca}^{2+}, \mathrm{Mg}^{2+}, \mathrm{Cl}^{-}, \mathrm{Br}^{-}, \mathrm{SO}_{4}{ }^{2-}, \mathrm{CO}_{3}{ }^{2-}, \mathrm{HCO}_{3}{ }^{-}, \mathrm{NO}_{3}{ }^{-}\right), \mathrm{F}^{-}$and $\mathrm{Br}^{-}$were determined, in laboratory, according to standard analytical methods. Samples were also subjected to isotopic analysis of $\delta^{18} \mathrm{O}$ and $\delta^{2} \mathrm{H}$.

The chemical analyses of the mud of the lake gave results, which were slightly modified from the results of previous analyses (Aggelidis, 1990). The dissolved components in the water (in g/Kg), are: $\mathrm{Na}^{+}(56,4), \mathrm{K}^{+}(0,32), \mathrm{Ca}^{2+}(0,09), \mathrm{Mg}^{2+}(0,09), \mathrm{Cl}^{-}(60,3), \mathrm{SO}_{4}{ }^{2-}(26,9), \mathrm{CO}_{3}{ }^{2-}(4,1), \mathrm{HCO}_{3}{ }^{-}$ $(4,1), \mathrm{F}^{-}(0,32)$. The dissolved salts in $\mathrm{HCl}$ are: $\mathrm{CaCO}_{3}(8,9 \%), \mathrm{MgCO}_{3}(3,2 \%) \quad \mathrm{kal}^{\mathrm{Fe}} \mathrm{Fe}_{2} \mathrm{O}_{3}(1,9 \%)$. The chemical analyses of the argillaceous clay of the mud (\%к. $\beta$.) gave: $\mathrm{Na}_{2} \mathrm{O}(2,4 \%), \mathrm{K}_{2} \mathrm{O}(2,5 \%)$, $\mathrm{MgO}(1,6 \%), \mathrm{CaO}(0,3 \%), \mathrm{Al}_{2} \mathrm{O}_{3}(16,5 \%), \mathrm{Fe}_{2} \mathrm{O}_{3}(4,3 \%), \mathrm{Kal}_{\mathrm{I}} \mathrm{SiO}_{2}(36,5 \%)$. The argillaceous clay is

The trace elements (in $\mathrm{mg} / \mathrm{Kg}$ ) of the clay (consisted of montmorillonite, mica, albite, kaolinite, feldspars and quartz), are: $\mathrm{As}$ (140 B (650), $\mathrm{Br}(210), \mathrm{Ba}(930), \mathrm{Sd}(2), \mathrm{U}(6), \mathrm{Cr}(92), \mathrm{Zn}(79)$, Co (18), Cs (4).

\section{CHEMICAL AND ISOTOPIC RESULTS}

In Fig. 1 is presented the relationship between oxygen-18 and the deuterium contents of the samples. At the same diagram, the global meteoric water line (GMWL) (Graig, 1961,a,b), the domain of seawater (Standard Mean Ocean Water) and the seawater evaporation line are also marked.

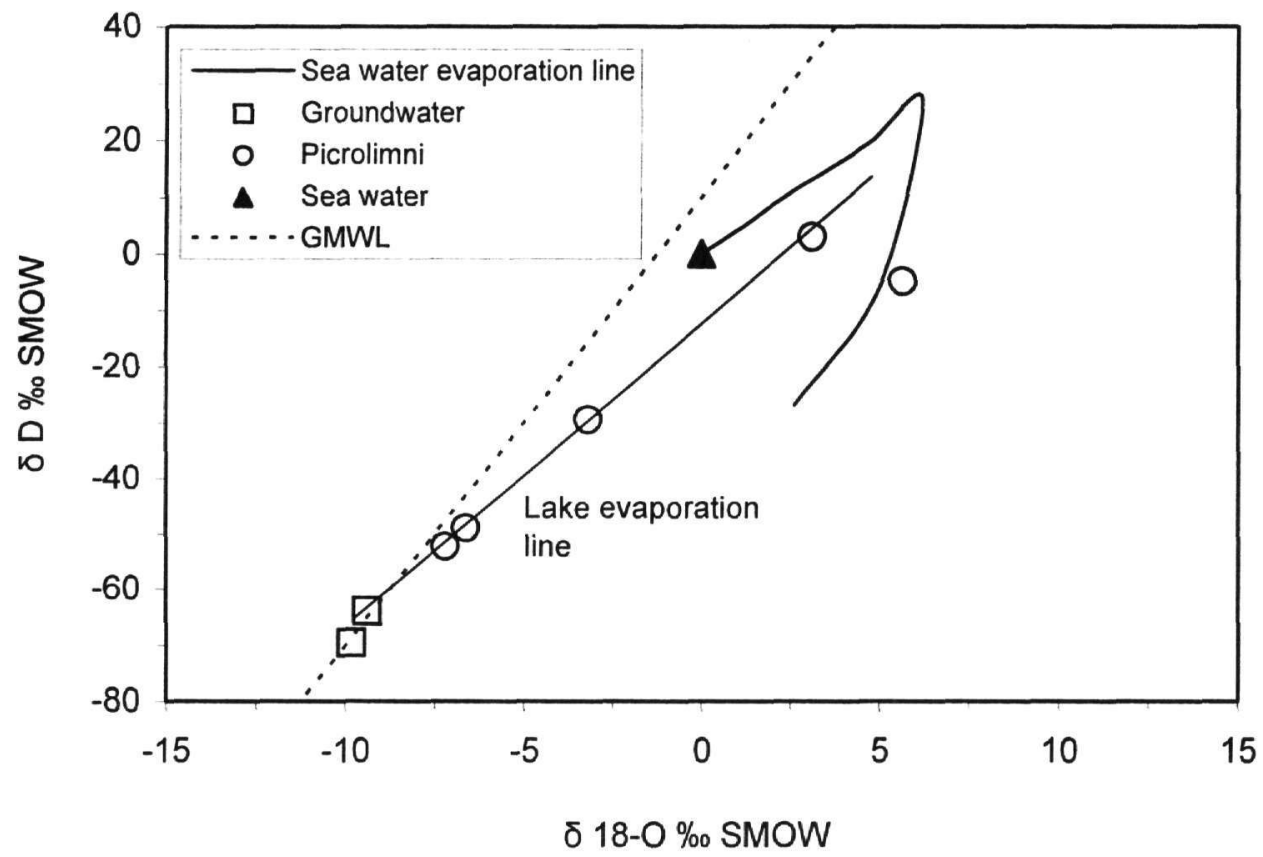

Fig.1: $\delta^{2} \mathrm{H}$ and $\delta^{18} \mathrm{O}$ contents of the water (groundwater and brine) of Pikrolimni area.

The position of samples from borehole is very close to that of mean meteoric water, confirming its purely meteoric water composition.

The $\delta^{2} \mathrm{H}$ and $\delta^{18} \mathrm{O}$ contents of the water of Pikrolimni Lake lie to the right of the meteoric line.

This isotopic data, indicate the evolution of the evaporation of the water of the lake during time, leading to the isotopic enrichment from winter $\left[\delta^{18} O(2 / 2003)=-7,22 \% 0\right)$ to summer $\left[\delta^{18} O\right.$ $(8 / 2003)=3,1 \%$ and $\delta^{18} \mathrm{O}(8 / 2002)=5,6 \%$. This means that during summer the evaporating conditions are such that conduce to the total evaporation of the water of the lake, producing thus 
brine with notable $\delta^{18} \mathrm{O}$ and $\delta^{2} \mathrm{H}$ enrichment, and salts. During winter, the meteoric water, which fills the lake, dilutes completely the brines and recycles the earlier salts, reflecting most probably a past climatic event. Therefore, the line of the water of Pikrolimni lake, that is depicted in the $\delta^{2} \mathrm{H}$ and $\delta^{18} \mathrm{O}$ diagram, is a line of evaporation having a slope of 5.35 , value that depends on the local environmental conditions.

This purely meteoric character of the water Lake does not appear using chemical tracers.

The results from the chemical analyses of the samples, show that the waters taken from the borehole, are of the type $\mathrm{Mg}-(\mathrm{Na}-\mathrm{Ca})-\mathrm{HCO}_{3}$ and the salts of the lake are of the type $\mathrm{Na}-\mathrm{Cl}-\left(\mathrm{CO}_{3}\right.$ $\mathrm{SO}_{4}$ ). The $\mathrm{Cl}^{-}$and $\mathrm{Br}^{-}$are considered to be conservative ions and very appropriate even in 'very salt' environments. Their behavior is thus particularly interesting in studies of the origin of salinity. In the diagram of figure 2, the $\mathrm{Cl}$ versus $\mathrm{Br}^{-}$contents of the borehole in the thermal spa of Pikrolimni, the domain of seawater (dilution and evaporation of sea water), the domain of the salts (Pierre, 1982) precipitated from the seawater and the domain of brine from the lake of Pikrolimni are illustrated.

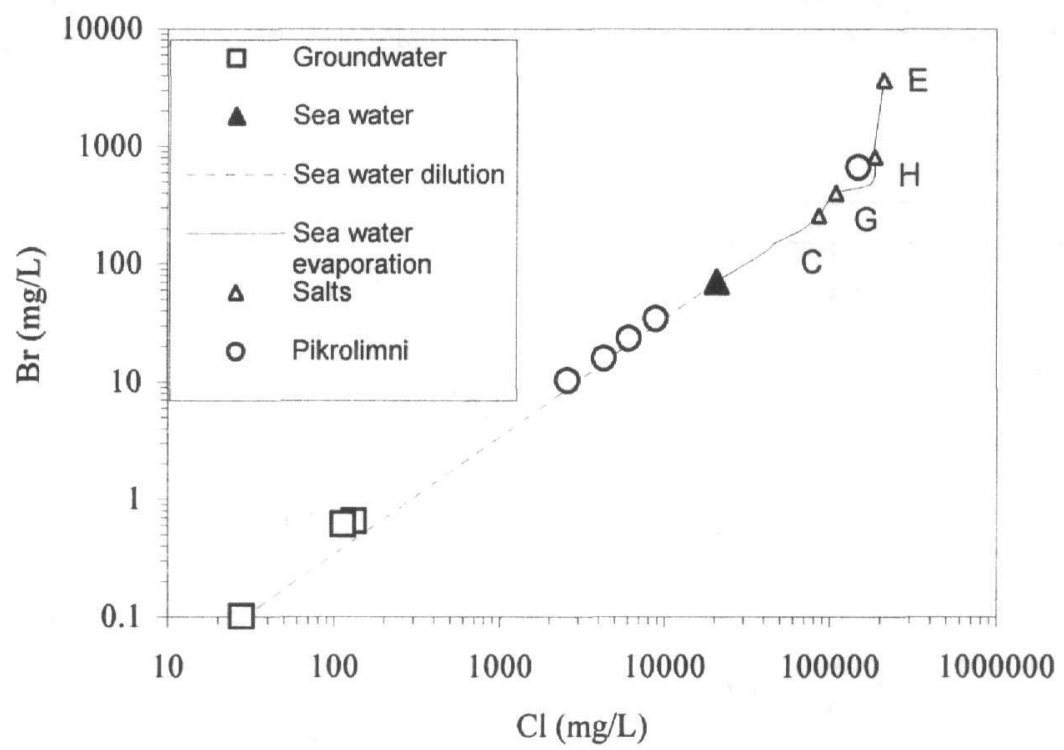

Fig. 2: $\mathrm{Cl}$ versus $\mathrm{Br}^{-}$contents of the water (groundwater and brine) of Pikrolimni area. Open triangle the domain of the salts (C: calcite, G: gypsum, H: halite, E: epsomite).

In that diagram the homogeneity of $\mathrm{Cl} / \mathrm{Br}$ ratio suggests a 'source' unique of salinity. In particular, the $\mathrm{Cl}^{-} / \mathrm{Br}^{-}$ratio of the samples is similar to the seawater $\mathrm{Cl}^{-} / \mathrm{Br}^{-}$ratio suggesting that $\mathrm{Cl}^{-}$, $\mathrm{Br}^{-}$derive from seawater (marine aerosol or actual seawater intrusion in the system?). In particularly the borehole groundwater contains a small marine component, which is of rather small significance but becomes important because of its accumulation during time. This means that every year for thousands of years, total evaporation of the water of the lake and total dilution of precipitated salts from fresh waters, ground- or surface-, which supply the lake, occurred. These facts conduce to the continuous enrichment of conservative ions, which can be regarded as marine tracers. This marine component is one of the alimentation components of the lake. However, the main component however, is fresh water (meteoric and ground water enriched in $\mathrm{Na}^{+}, \mathrm{Ca}^{2+}$, carbonates and bicarbonates with basic $\mathrm{pH}$ ), which circulates deeply and is probably mixed with water of deeper and warmer horizons. The latter comes in agreement with the hydrothermal field, which exists in the area. The evaporation of the water of the lake leads to the formation of alkaline brines. The gradual concentration of this water reinforces the progressive elevation of the ions and this continental 
water sources produce mainly sodium carbonate and minor amounts of calcium carbonate. Because of the high amount of chlorine-ions in the Pikrolimni lacustrine environment, a further concentration of the waters of the lake produces halite.

\section{SIMULATION EXPERIMENTS}

The evaporation of salt of Pikrolimni lake water in the laboratory gave the following sequential of the salts: Burkeite $\left(\mathrm{Na}_{2} \mathrm{CO}_{3}{ }^{*} 2 \mathrm{Na}_{2} \mathrm{SO}_{4}\right)$, Trona $\left(\mathrm{Na}_{2} \mathrm{CO}_{3}{ }^{*} \mathrm{NaHCO}_{3}{ }^{*} 2 \mathrm{H}_{2} \mathrm{O}\right)$ and Halite $(\mathrm{NaCl})$ (Dotsika et al., 2003).

This result confirms that the evaporating conditions, which dominated sometime in the past, converted the Lake water into alkaline brine. Besides, the progressive concentration of brines in alkaline Lakes leads to a preferential precipitation of sodium carbonate followed by sulfates and chlorides (Sonnenfeld, 1984).

\section{CONCLUSIONS}

The salts of the lake result from mixing and condensation of the waters which are accumulated in the basin of the lake, and come not only from sources that feed the lake, e.g. waters from borehole, but also from rain water. The waters of these sources are mainly of meteoritic origin and circulate deeply, mixing probably with salt water of deeper and probably of warmer horizons. The latter comes in agreement with the hydrothermal field, which exists in the area. From hydrochemical data, the brines of summer clearly correspond to waters, which have been submitted under high degree of evaporation: they are residual mother solutions before the step of the precipitation of halite.

During winter, dilution of brines and dissolution of depositing minerals by meteoric water are observed. On the other hand, evaporating conditions are created in the lake during summer.

The work is still under progress but from the preliminary results, it is hydro-chemically possible for this lake to have been the source of the "nitrum chalestricum".

\section{REFERENCES}

Aggelidis Z. 1990, Emergence of clay deposits in Grecce and possibilities of exploitation in therapeutic tourism. $2^{\text {nd }}$ congress of thermo-metallic waters. Thessaloniki,7-9 October 1988. pages 74-88. (in Greek).

Graig H., 1961a - Standard for reporting concentrations of deuterium and oxygen 18 in natural waters. Science, 133, 1833 - 1934

Graig H., 1961b - Isotopic variations in meteoric waters. Science, 133, 1702-1703.

Pierre C. 1982 - Teneurs en isotopes stables $\left({ }^{18} \mathrm{O},{ }^{2} \mathrm{H},{ }^{13} \mathrm{C},{ }^{34} \mathrm{~S}\right)$ et conditions de genese de evaorites marines: application a quelques milieux actuels et au Messinien de la Mediterranee. These Doct. Sci. Nat., Univ. Paris-Sud, 266p.

Sonnenfeld P. (1984), Brines and Evaporites, Academic Press, INC, p. 613.

Ignatiadoy Despina, Dotsika El. and Maniatis Y., 2003 - Nitrum Chelestricum. The natron of Macedonia. Association Internationale pour l'Histoire du Verre $16^{\text {th }}$ Congress, London September $7^{\text {th }}-13^{\text {th }} 2003$.

Dotsika E., Maniatis Y. and Ignatiadoy D., 2003 - A natron source for glass making in Greece ; : Preliminary

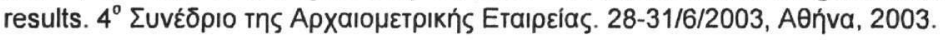

